\title{
Orobanche RESISTANCE IN SUNFLOWER
}

\author{
Höniges, A., Wegmann, K. ${ }^{*}$ and Ardelean, A.
}

Universitatea de Vest „Vasile Goldiş“, Arad, Romania

Received: October 20, 2008

Accepted: December 10, 2008

SUMMARY

This report presents the current knowledge of Orobanche resistance in sunflower from the breeder's standpoint and from the biochemists' standpoint.

The parasitic relations in Helianthus annuus / Orobanche cumana associations differ in many respect from relations of other Orobanche spp. and their hosts.

A major difficulty for the breeder is the fast development of new pathotypes of Orobanche cumana, which overcome the resistance of newly developed sunflower lines. The basis of increasing aggressiveness of Orobanche cumana pathotypes is discussed. Nevertheless, there is still large potential for resistance breeding in the genus Helianthus, since very different resistance factors are already known or shall be elucidated.

A survey is presented of known resistance factors, such as low stimulants, mechanical barriers and how they develop, phytoalexins, Orobanche seed germination inhibitors, inhibition of exoenzymes of the Orobanche radicles, in particular of polygalacturonase, which enables the penetration of Orobanche tissue into the host root along the middle lamellae. In this context an interesting new approach may be found in the polygalacturonase-inhibiting proteins occurring in cell walls, which inhibit the invasion of pathogenic fungi.

The need for molecular biological studies will be stressed. Interdisciplinary collaboration of breeders with biochemists and molecular biologists may lead to more advanced breeding strategies.

\section{Key words: sunflower, Orobanche cumana resistance, resistance factors, phytoalexins, polygalacturonase inhibitors, phytoalexins}

\section{INTRODUCTION}

The root parasitic angiosperm Orobanche cumana is a major problem in sunflower in all south European countries and Turkey. While biological control has so far been unsuccessful, and the application of herbicides is limited for health and economic reasons, only resistance breeding provides a long-term solution. Compared with other Orobanche/crop systems Helianthus annuus/Orobanche cumana systems differ in two important details. Germination stimulants from sunflower

* Corresponding author: e-mail: Wegmann@uvvg.ro 
(parthenolide and related compounds) are specific for $O$. cumana (Pérez-de-Luque et al., 2000, Pérez-de-Luque et al., 2001, Chaudhuri et al., 2006), while other Orobanche species are stimulated by strigolactones, and the parasite O. cumana rapidly evolves new, increasingly dangerous pathotypes.

\section{RESULT AND DISCUSSION}

\section{Orobanche resistance from the breeder's standpoint}

The fast evolution of new pathotypes is characteristic for Orobanche cumana. They were called race A, B, C, D, E, and for each of them a resistance gene was identified, Or1, Or2, Or3, Or4 and Or5, respectively. These resistance genes are monogenically and dominantly inherited. However, in some cases, the influence of a still unidentified gene has been discussed (cytoplasmic; Russell, 1981), which might make the resistance a quantitative factor, depending for example on temperature.

Generally a root-specific promoter can be expected, which controls the expression of resistance gene(s) upon infection.

While the chemical nature of resistance factors has been studied, neither of these factors has been assigned to one of the Or genes until now.

Turbo, Favorit, Alcazar, Florina and Justin were Romanian sunflower lines resistant to O. cumana which carried Or1-Or5 genes.

The situation became complicated for sunflower breeders around 1980, when a new $O$. cumana race $\mathrm{F}$ occurred in south-east Romania. Pacureanu-Ioita identified a resistance gene Or6. At the COST 849 Meeting held in Reading in 2005, she reported about trials with resistant sunflower lines organized in Braila and in Spain. Odessa 507-1 proved resistant to $\mathrm{F}$ race in Braila but not in Spain while KR$3-2 b$ proved resistant in Spain but not in Braila. This meant that the $F$ lines from Braila and Spain were not identical.

Mold-1-2 line, Kiz 321-3-3b line, VYP-70-4 population and Alinka-1 population were resistant to $\mathrm{F}$ races from Romania and Spain, but were sensitive to broomape from Turkey. Did that mean that a new race G existed in Turkey?

$O$. cumana race $\mathrm{F}$ in Russia is called biotype $\mathrm{D}$. Such discrepancies in nomenclature should strictly be avoided.

Better knowledge of Orobanche cumana races (pathotypes) is useful for breeders. Identification of races has become possible by molecular biological analysis (Román et al., 2007).

The sunflower inbred line KI-374 is resistant to race F. Crosses were carried out between the Orobanche-susceptible line HA300 and the KI-6 line, which carries the Or5 gene of resistance. The evaluation of $\mathrm{F}_{1}, \mathrm{~F}_{2}, \mathrm{BC}_{1} \mathrm{P}_{1}$ and $\mathrm{BC}_{1} \mathrm{P}_{2}$ progenies of both crosses indicated that the inheritance of resistance to broomrape in KI374 is 
due to two independent recessive genes: Or6 and Or7 (Rodriguez-Ojeda et al., 2001).

The occurrence of a new pathotype overcoming sunflower resistance may indicate a gene-for-gene relation. The new pathotype has either a higher aggressiveness or a new specificity; this is not necessarily the same. The breeder should combine at least two independent resistance factors in order to interrupt the gene-for-gene development. The parasite cannot overcome two different resistances at the same time. This strategy has recently been applied by Pacureanu-Ioita et al. (2008). The line AO-548 carries two independent dominant resistance genes and is fully resistant to all $O$. cumana pathotypes.

\section{Sources of resistance genes}

There is common agreement among sunflower breeders that some wild annual and almost all perennial Helianthus species (Fernandez-Martinez et al., 2000, Nikolova et al., 2000, Fernandez-Martinez et al., 2004, Bervillé 2004) are potential sources of resistance genes against Orobanche cumana.

Pérez-Vich et al. (2002) studied the inheritance of resistance to race F derived from interspecific amphiploids of $H$. annuus and two wild perennials, $H$. divaricatus and $H$. grosseserratus. They suggested that the resistance is controlled by a single dominant gene. In a re-examination by the same working group (Velasco et al., 2007), however, the resistance of the sunflower variety J1, derived from $H$. grosseserratus, proved to be digenic, the second gene being influenced by environmental factors.

During the COST 849 Meeting in Athens in 2003, Pacureanu-Ioita has reported about sources of resistance in Helianthus divaricatus, H. mutelii, H. grosseserratus and H. tuberosus (Marinescu and Pacureanu-Ioita, 2002).

At the COST 849 Meeting in Naples in 2004, Wegmann mentioned microscopic studies conducted by Teryokhin in Wegmann's laboratory (1997). Several perennial Helianthus species stimulated Orobanche germination but the radicle could not penetrate the host root.

Batchvarova et al. (2001) worked with mutant lines after ${ }^{60} \mathrm{Co}$ irradiation of cultivar VNIIMK and others and found promising results concerning resistance to highly aggressive $O$. cumana races in northern Bulgaria.

There are several reports about $O$. cumana resistance in cultivated sunflower lines. Lines VB 3090, VB 24 and VB 368 are considered totally resistant to $O$. cumana, including the new races (Tikhomirov and Chiryaev, 2005). Four sunflower populations have been released as resistant to $O$. cumana race F: BR1, BR2, BR3, BR4 (Martinez et al., 2002). Resistant hybrids have also been released in Russia (Gontcharov et al., 2004) and in Turkey (Kaya et al., 2004). 


\section{Orobanche resistance from the biochemist's standpoint}

The breeder ascribes resistance to genes and studies their inheritance, while the biochemist searches for biochemical resistance factors and resistance mechanisms, the causal relation between chemical compounds and resistance.

During the $1^{\text {st }}$ Orobanche Workshop in Wageningen, Wegmann (1986) has proposed a number of tentative resistance factors against Orobanche. In the meantime, much effort has been invested into investigations of resistance factors, the list of tentative resistance factors was extended, and there is considerable progress in understanding Orobanche resistance.

"Low stimulant", the exudation of insufficient amount of germination stimulant is a weak resistance factor. To our knowledge, "low stimulant" is not known in any Helianthus line or wild species. Moreover, "low stimulant" could also be mimicked by the presence of germination inhibitors.

Mechanical barriers, like lignification of the cell wall by peroxidase-catalyzed reactions could probably play a role. In his PhD work, Labrousse (2002) has compared several Helianthus genotypes concerning their defence mechanisms against Orobanche cumana. The resistant genotype LR1 deposits callose inside the xylem in close contact with the parasite, due to an overexpression of the callose synthase cDNA gene HaGSLI (Delavault et al., 2006). In some cases vessels were completely closed, so that water and nutrients could not flow to the parasite. A defensin gene has been identified in LR1 genotype, which is correlated with Orobanche resistance (Letousey et al., 2007). In the wild relative Helianthus debilis debilis, an encapsulation layer stopps the intrusion of the parasite. Pérez-de-Luque et al. (2006) have shown by cytochemical studies, however, using peas resistant to O. crenata, that protein crosslinking, peroxidase and ß-1,3-endoglucanase are involved in Orobanche resistance. These findings have also been reported for sunflower resistance to $O$. cumana by Echevarría-Zomeño et al. (2006).

Phytoalexins as resistance factors against Orobanche have been hypothesized for the first time by Wegmann (1986). Phytoalexins are valuable resistance factors. They are low molecular weight secondary metabolites, which serve the plant in selfdefence: they are only synthesized after the attack by a pathogen. Examples for phytoalexin-caused resistance have been identified by Wegmann et al. (1991) for sunflower $c v$. 81-14 and chickpea cv. ILC 280. The toxicity of phytoalexins to Orobanche was shown in submersed Orobanche cell cultures. Since then the phytoalexin concept has developed considerably.

When the attacked root responds by a hypersensitive reaction, necrosis and the subsequent death of the parasite, the search for phytoalexins should be carried out. Phytoalexins are generally simply inherited.

The phytoalexin concept has been adopted by Jorrín, who, during the COST 849 Meeting in Bari in 2001, confirmed the synthesis of 7-hydroxylated coumarins, 
scopoletin and ayapin, in the defence system of sunflower against Orobanche. See also Serghini et al. (2001).

Phytoalexins are active defence compounds only if they are produced fast enough and in sufficient local concentration. This was supported by studies of susceptible and resistant sunflower lines (Letousey et al., 2004). A phytotoxic root extract from the resistant sunflower variety Amber (Eizenberg et al., 2001) may, according to its effect on established invaders and due to its chemical behaviour, be considered a chemically yet unidentified phytoalexin. The resistance of Amber, which is observed only at high temperature (Eizenberg et al., 2003), may indicate that a temperature-controlled gene is involved in the synthesis of the toxic compound.

"Plant fortifiers" BTH (Bion) (Buschmann et al., 2001, Sauerborn et al., 2002) or prohexadione-calcium (Fan et al., 2007) induce dystemic scquired resistance (SAR), fortify phytoalexin formation and therefore contribute to resistance against Orobanche cumana without affecting the parasite itself.

Germination inhibitors. If the (non)host plant would exude germination inhibitors for Orobanche seed, this could be an efficient resistance factor. The sunflower phytoalexins scopoletin and ayapin showed germination inhibiting activity, when germination was induced by the synthetic stimulant GR24 (Pérez-de-Luque et al., 2001). The search for germination inhibitors shall be continued.

Inhibition of the germ tube (Orobanche radicle) exoenzymes. Wegmann (2004) proposed the search for inhibitors of the germ tube exoenzymes and germination inhibitors as resistance factors at the COST 849 Meeting in Naples in 2004. Pectinases have always been found the most active enzymes in the exudates of Orobanche radicles. This fits well to microscopic studies by Ben-Hod et al. (1993) according to which the radicle invades the host root tissue along the middle lamellae. Inhibition of polygalacturonase (EC 3.2.1.15) and pectinmethylesterase (EC 3.2.1.11) by root exudates could be a perfect resistance factor, because the penetration of the Orobanche radicle into the root is inhibited. There are a number of metabolites, particularly from the phenylpropanoid pathway, which are known inhibitors for enzymes. Their inheritance is not yet investigated, however, simple inheritance is expected. An indication for the existence of such resistance factors is the microscopic observation (Teryokhin, Wegmann) that germ tubes in certain cases touch the host root and even bend around it, but do not penetrate it.

Little attention has so far been given to polygalacturonase-inhibiting proteins (PGIPs), well known in fungal resistance of higher plants, discovered by Albersheim et al. (1971). These are widespread, leucin-rich cell wall proteins, which bind tightly to polygalacturonases and inhibit them (De Lorenzo et al., 2001). The PGIPs family exhibits specificity for polygalacturonases. This could distinguish resistant from susceptible hosts, and possibly could contribute to understanding host specificity. 
Evidence for unfavorable phytohormone supply from the host root to the haustorium, which does not allow normal development of the parasite, has been observed in the Linum usitatissimum/Orobanche ramosa system (Chen, 1991). The tubercle remains small and differentiates too early with the formation of tiny leaflets on the tubercle surface. However, for breeding programs these findings are difficult to handle, as the inheritance of phytohormone concentration ratios is polygenic, and it may also vary with host development, environmental conditions and host nutrition.

\section{Aggressiveness}

Antonova (1994) and Antonova and ter Borg (1996) have presented data on peroxidases in Orobanche cumana races. The races differ insofar as they exude the peroxidase or keep it inside their cells. The exudation of peroxidase causes defence action of the attacked root cells (brown staining is observed; oxidation of polyphenols?). The more virulent form (race D) does not exude peroxidase, thus avoiding the host's reaction. Also differences in pectinases in differently virulent Orobanche cumana races could be a reason for different aggressive performance of parasite pathotypes (Simier et al., 2004). More active exoenzymes for germ tube penetration into the host root could partly overcome defence reactions of the host. The metabolic decomposition of phytoalexins by Orobanche tissue (shown for the decomposition of scopoletin, Wegmann et al., 1991) would be another example for increased aggressiveness.

\section{Molecular biological studies on Orobanche resistance}

Unlike very complex and polygenic traits such as drought resistance, Orobanche resistance similar to disease resistances is accessible for gene analytical studies. In sunflower, marker assisted selection for resistance to downy mildew (Brahm et al., 2000) and male sterility (Pérez-Vich et al., 2005) has been carried out.

All authors working with Orobanche cumana resistance to sunflower have so far concentrated to the Or5 gene, probably because this is a dominant gene with simple resistance to race $\mathrm{E}$ of Orobanche cumana. Genetic mapping of the Or5 gene was carried out by Tang et al. (2003), where all the problems of the genetic analysis of a "simple gene" are found. These studies do not reflect "genomic analysis of Orobanche resistance" but just the presence of the Or5 gene.

Guantitative traits loci (QTLS) need to be identified to correlate genomic analysis with various phenomena of resistance. Bervillé et al. (2001) presented strategies for QTL mapping in interspecific progenies between the cultivated and wild Helianthus forms and discussed the problems arising during selection for Orobanche resistance.

Pérez-Vich et al. (2004) suggested that resistance to Orobanche cumana in sunflower is controlled by a combination of qualitative, race-specific resistance 
genes affecting the presence or absence of broomrape and a quantitative non-race specific resistance affecting the number of infections. The biochemist's task is to identify the two different resistance factors.

Pérez-Vich et al. (2004) have reported about QTL mapping of resistance to broomrape races E and F (Orobanche cumana Wallr.) in sunflower. Sunflower line $\mathrm{P}-96$ shows dominant resistance to race $\mathrm{E}$ and recessive resistance to race $\mathrm{F}$. Crossing P-96 with the susceptible line P-21 was phenotyped for broomrape resistance in four experiments, two for $\mathrm{E}$ and two for $\mathrm{F}$, and was genotyped with microsatellite and RFLP markers. A linkage map comprising 103 marker loci distributed on 17 linkage groups was developed, and composite interval mapping analyses were performed. Five QTLs (or 1.1, or3.1, or7.1, or 13.1, and or 13.2) for resistance to race E, and 6 QTLs (or1.1, or 4.1, or5.1, or 13.1, or 13.2 and or 16.1) for resistance to race F were detected on 7 of the 17 linkage groups. Iuoras et al. (2004a) and Iuoras et al. (2004b) studied the use of marker-assisted selection for resistance to Orobanche cumana Wallr. in sunflower. Sunflower line LC1093 as carrier of resistance to race $\mathrm{E}$ has been used for hybridization. For marker-assisted selection the RAPD markers UBC73, UBC318, UBC264, UBC685 and OP-A17, and the SSR markers ORS1114 and ORS1036 proved useful for the analysis of $\mathrm{F}_{2}$ and $\mathrm{BC}_{1}$ generations. The crucial point of the correlations of QTLs with genomic analysis is the dependence of Orobanche resistance (different pathotypes) on environmental factors. Here is the greatest opportunity for cooperation of breeders/geneticists and biochemists.

\section{CONCLUSIONS}

There is still a great potential of Orobanche resistance factors, which has not yet been exploited for Orobanche resistance breeding in sunflower.

In order to avoid overcoming resistance by the evolution of new pathotypes (races) of Orobanche cumana, the combination of at least two independently acting resistance factors in sunflower breeding is recommended.

Interdisciplinary cooperation between breeders/geneticists and biochemists could lead to faster progress in sunflower breeding.

\section{REFERENCES}

Albersheim, P., Anderson, A.J., 1971. Proteins from plant cell walls inhibit polygalacturonases secreted by plant pathogens. Proc. Nat. Acad. Sci. USA 68: 1815-1819.

Antonova, T.S., 1994. Biochemical aspects of the development of new virulent forms of the Moldavian population (race C) of Orobanche cumana Wallr. against the background of resistant cultivars. In: Pieterse, A.H., Verkleij, J.A.C. and ter Borg, S.J. (eds.) Proceedings Third International Workshop on Orobanche and related Striga Research, Amsterdam, The Netherlands, pp. 290-292.

Antonova, T.S., ter Borg, S.J., 1996. The role of peroxidase in the resistance of sunflower against Orobanche cumana in Russia. Weed Research 36: 113-121. 
Batchvarova, R., Hristov, M., Slavov, S., Valkov, V., 2001. Development of sunflower lines resistant to Orobanche cumana Wallr. through mutagenesis and interspecific hybridisation. $7^{\text {th }}$ International Parasitic Weed Symposium, Nantes, France, pp. 234.

Bervillé, A., 2002. Perennial sunflower in breeding for resistance. COST 849 Meeting, Sofia, Bulgaria.

Bervillé, A., Langar, K., Labrousse, P., Serieys, H., Griveau, Y., Thalouarn, P., 2001. Strategies for QTL mapping in interspecific progenies between a cultivated and a wild form: Applications to sunflower for two diseases, one fungal: Phomopsis, and one parasitic: Orobanche. Proc. $7^{\text {th }}$ International Parasitic Weed Symposium, Nantes, France, pp. 160165.

Brahm, L., Röcker, T., Friedt, W., 2000. PCR-based markers facilitating marker assisted selection in sunflowers for resistance to downy mildew. Crop Science 40: 676-682.

Buschmann, H., Ghiavi, K.G., Sauerborn, J., 2001. Induced resistance in sunflower against Orobanche cumana. $7^{\text {th }}$ International Parasitic Weed Symposium, Nantes, France, pp. 233.

Chaudhuri, S.K., Joel, D.M., Steffens, J.C., 2006. Does the germination stimulant for Orobanche cumana differ from strigolactones? COST 849 Meeting, Lisbon, Portugal.

Chen, J.P., 1991. Biologische und chemische Untersuchungen über die Ursachen der Resistenz von Lein (Linum usitatissimum) gegen Orobanche. Diploma-Thesis Univ. Tübingen.

Delavault, P., de Zélicourt, A., Letousey, P., Thoiron, S., 2006. Molecular analysis of sunflower resistance mechanisms to Orobanche cumana. COST 849 Meeting, Lisbon, Portugal.

Delorenzo, G., D’Ovidio, R., Cervone, F., 2001. The role of polygalacturonase-inhibiting proteins (PGIPs) in defence against pathogenic fungi. Ann. Rev. Phytopathology 39: 313335.

Eizenberg, H., Plakhine, D., Dor, E., Hershenhorn, J., Kleifeld, Y., Rubin, B., 2001. Phytotoxic root extract from resistant sunflower (Helianthus annuus L. $c v$. AMBAR) inhibits Orobanche cumana development. In: A. Fer, P. Thalouarn, D.M. Joel, L.J. Musselman, C. Parker, J.A.C. Verkleij (eds.) Proceedings $7^{\text {th }}$ International Parasitic Weed Symposium, Nantes, France, pp. 190.

Eizenberg, H., Plakhine, D., Hershenhorn, J., Kleifeld, Y., Rubin, B., 2003. Resistance to broomrape (Orobanche spp.) in sunflower (Helianthus annuus L.) is temperature dependent. J. Exp. Bot. 54: 1305-1311.

Eschevarría-Zomeño, S., Pérez-de-Luque, A., Jorrin, J., Maldonado, A.M., 2006. Pre-haustorial resistance to broomrape (Orobanche cumana) in sunflower (Helianthus annuus): cytochemical studies. J. Exp. Bot. 57: 4189-4200.

Fan, Z.W., Buschmann, H., Sauerborn, J., 2007. Prohexadione-calcium induces sunflower (Helianthus annuus) resistance against the root parasitic weed Orobanche cumana. Weed Research 47: 34-43.

Fernandez-Martinez, J., Meléro-Vara, J., Muñoz-Rus, J., Ruso, J., Dominguez, J., 2000. Selection of wild and cultivated sunflower for resistance to a new broomrape race that overcomes resistance to the Or5 gene. Crop Science 40: 550-555.

Fernandez-Martinez, J.M., Velasco, L., Pérez-Vich, P., 2004. Resistance to the new highly virulent races of sunflower broomrape (Orobanche cumana Wallr.): Sources of variation and genetic studies. COST 849 Meeting Bucharest, Romania.

Gontcharov, S.V., Antonova, T.S., Araslanova, N.M., 2004, Sunflower breeding for resistance to the new broomrape race. Helia 27(40): 193-198.

Iuoras, M., Stanciu, D., Ciuca, M., Pacureanu, M., 2004. Preliminary studies related to the use of marker assisted selection for Orobanche cumana Wallr. COST 849 Meeting Bucharest, Romania.

Iuoras, M., Stanciu, D., Ciuca, M., Nastase, D., Geronzi, F., 2004. Preliminary studies related to the use of marker assisted selection for resistance to Orobanche cumana Wallr. in sunflower. Romanian Agricultural Research 21: 33-37.

Jorrín, J., Ports, E., Ruso, J., 2001. Coumarin biosynthesis induction in sunflower as a defense strategy against broomrape. COST 849 Meeting. Bari, Italy.

Kaya, Y., Demirci, M., Avci, G., 2004. Sunflower (Helianthus annuus L.) breeding in Turkey for broomrape (Orobanche cernua Loeffl.) and herbicide resistance. Helia 27(40): 199210 .

Labrousse, P., 2002. Study of Orobanche cumana Wallr. (Orobanchaceae) resistance in several Helianthus (Asteraceae) genotypes. PhD thesis University of Nantes. France. 
Letousey, P., Dos Santos, C.V., Labrousse, P., Thalouarn, P., Delavault, P., 2004. Comparison of susceptible and resistant sunflowers to Orobanche cumana: physiological, molecular and genetic aspects. COST 849 Meeting. Bucharest, Romania.

Letousey, P., de Zelicourt, A., Dos Santos, C.V., Monteau, F., Simier, P., Thalouarn, P., Delavault, P., 2007. Molecular analysis of resistance mechanisms to Orobanche cumana in sunflower. Plant Pathology 56: 536-546.

Lu, Y.H., Gagne, G., Greezes-Besset, B., Blanchard, P., 1998. Integration of a molecular linkage group containing the broomrape resistance gene Or5 into an RFLP map in sunflower. Genome 42: 453-456.

Martinez, J.M., Ruso, J., Muñoz-Ruz, J., 2004. Registration of four sunflower germplasms with resistance to Orobanche cumana race F. Crop Science 42: 2217-2218.

Nikolova, L., Shindrova, P., Entcheva, V., 2000. Resistance to diseases, obtained through interspecific hybridization. Helia 23(33): 57-64.

Nikolova, L., 2004. Results from interspecific hybridization between Helianthus grosseserratus Martens and H. annuus L. Bulgarian Journal of Agricultural Science 10: 291-298.

Pacureanu-Ioita, M., Procopovici, E., 2003. Broomrape control in Romania. COST 849 Meeting, Athens.

Pacureanu-Ioita, M., Raranciuc, S., Procopovici, E., Sava, E., Nastase, D., 2008. The impact of the new races of broomrape (Orobanche cumana Wallr.) parasite in sunflower crop in Romania. Proceedings $17^{\text {th }}$ International Sunflower Conference, Córdoba, Spain, pp. 225-229.

Pérez-de-Luque, A., Galindo, J.C.G., Macias, F.A., Jorrín, J., 2000. Sunflower sesquiterpene lactone models induce Orobanche cumana seed germination. Phytochemistry 58: 45-50.

Pérez-de-Luque, A., Rubiales, D., Galindo, J.C.G., Macias, F.A., JorrÍn, J., 2001. Allelopathy and allelochemicals within the plant-parasitic weed interaction. Studies with the sunflower-Orobanche cumana system. $7^{\text {th }}$ International Parasitic Weed Symposium, Nantes, France, pp. 197-200.

Pérez-de-Luque, A., Gonzales-Verdejo, C.I., Dolores Lozano, M., Dita, M.A., Cubero, J.I., Gonzales-Melendi, P., Risueno, M.C., Rubiales, D., 2006. Protein cross-linking, peroxidase and $ß-1,3$-endoglucanase involved in resistance of pea against Orobanche crenata. Journal of Experimental Botany 57: 1461-1469.

Pérez-Vich, B., Akhtouch, B., Muñoz-Ruz, J., Fernandez-Martinez, J.M., Jan, C.C., 2002. Inheritance of resistance to a highly virulent race $\mathrm{F}$ of Orobanche cumana Wallr. in a sunflower line derived from interspecific amphiploids. Helia 25(36): 137-144.

Pérez-Vich, P., Velasco, L., Fernandez-Martinez, J.M., 2004. QTL mapping of resistance to races $\mathrm{E}$ and $\mathrm{F}$ of broomrape (Orobanche cumana Wallr.) in sunflower. COST 849 Meeting, Bucharest, Romania.

Pérez-Vich, B., Akhtouch, B., Knapp, S.J., Leon, A.J., Velasco, L., Fernandez-Martinez, J.M., Berry, S.T., 2004. Quantitative trait loci for broomrape (Orobanche cumana Wallr.) resistance in sunflower. Theoretical and Applied Genetics 109: 92-102.

Pérez-Vich, B., Berry, S.T., Velasco, L., Fernandez-Martinez, J.M., Gandhi, S., Freeman, C., Heesacker, A., Knapp, S.J., Leon, A.J., 2005. Molecular mapping of nuclear male sterility genes in sunflower. Crop Science 45: 1851-1857.

Rodríguez-Ojeda, M.I., Fernández-Escobar, J. and Alonso, L.C., 2001. Sunflower inbred line (KI-374), carrying two recessive genes for resistance against a highly virulent Spanish population of Orobanche cernua Loelf./O. cumana Wallr. race $\mathrm{F}$. $7^{\text {th }}$ International Symposium on Parasitic Plants, Nantes, France.

Román, B., Verdejo, C.I.G., Satovic, Z., Madrid, M.D., Cubero, J.I., 2007. Detecting Orobanche species by using cpDNA diagnostic markers. Phytoparasitica 35: 129-135.

Russell, G.E., 1981. Plant breeding for pest and disease. Butterworth, London.

Sauerborn, J., Buschmann, H., Ghiasi, K.G., Kogel, H.-K., 2002. Benzothiadiazole activates resistance in sunflower (Helianthus annuus) to the root-parasitic weed Orobanche cumana. Phytopathology 92: 59-64.

Serghini, K., Pérez-de-Luque, A., Castejon-Munoz, M., Garcia Torres, L., JorrÍin, J.V., 2001. Sunflower (Helianthus annuus L.) response to broomrape (Orobanche cernua Loefl.) parasitism: Induced synthesis and excretion of 7-hydroxylated simple coumarin. J. of Exp. Bot. 52: 2227-2234.

Simier, P., Veronesi, C., Bonnin, E., Benharrat, H., Fer, A., Thalouarn, P., 2004. Aggressiveness and pectinolytic activities within populations of Orobanche cumana Wallr., a root parasite of sunflower. COST 849 Meeting, Cordoba, Spain. 
Tang, S., Heesacker, A., Kishore, V.K., Fernandez, A, El Sayed, S., Cole, G., Knapp, S.J., 2003. Genetic mapping of the Or5 gene for resistance to Orobanche race E in sunflower. Crop Science 43: 1021-1028.

Tikhomirov, V.T., Chiryaev, P.V., 2005. Sources of resistance to diseases in original material of sunflower. Helia 28(42): 101-106.

Velasco, L., Pérez-Vich, B., Jan, C.C., Fernandez-Martinez, J.M., 2007. Inheritance of resistance to broomrape (Orobanche cumana Wallr.) race $\mathrm{F}$ in sunflower line derived from wild sunflower species. Plant Breeding 126: 67-71.

Wegmann, K., 1986. Biochemistry of osmoregulation in Orobanche and possible biochemical basis of Orobanche resistance. In: S.J. ter Borg (eds.) Proceedings of a Workshop on Biology and Control of Orobanche, Wageningen, pp. 107-113.

Wegmann, K, von Elert, E., Harloff, H.-J., Stadler, M., 1991. Tolerance and resistance to Orobanche. In: K. Wegmann and L.J. Musselman (eds.) Progress in Orobanche Research pp. 318-321.

Wegmann, K., 2004. The search for inhibitors of the exoenzymes of the Orobanche radicle. COST 849 Meeting, Naples, Italy.

\section{RESISTENCIA A Orobanche EN GIRASOL}

\section{RESUMEN}

Este informe presenta el conocimiento actual acerca de la resistencia a Orobanche en girasol desde el punto de vista de los mejoradores y los bioquímicos.

Las relaciones de parasitismo en las asociaciones Helianthus annuus/ Orobanche cumana difieren de muchas maneras de otras relaciones entre Orobanche spp. con sus hospedantes.

Una dificultad severa para el mejorador es el rápido desarrollo de nuevos patotipos de Orobanche cumana que vencen la resistencia de las líneas de girasol desarrolladas recientemente. Se discuten las bases del incremento de la agresividad de los patotipos de Orobanche cumana. Sin embargo, hay todavía un gran potencial para la obtención de resistencia a través del mejoramiento en el género Helianthus, ya que muchos factores de resistencia son conocidos o deben ser dilucidados todavía.

Se presenta una revisión sobre factores de resistencia conocidos, como baja estimulación, barreras mecánicas y cómo éstas se desarrollan, fitoalexinas, inhibidores de la germinación de la semilla de Orobanche, inhibidores de las exoenzimas de las radículas de Orobanche, en particular poligalacturonasa, la que permite la penetración de los tejidos de Orobanche en la raíz del hospedante. En este contexto se puede encontrar una nueva aproximación interesante en las proteínas inhibidoras de la poligalacturonasa que se observan en las paredes celulares y que inhiben la invasión de hongos patogénicos.

Se discute la necesidad de estudios de biología molecular.

La colaboración interdisciplinaria de mejoradores con bioquímicos y biólogos moleculares puede generar estrategias de mejoramiento más avanzadas. 


\title{
RÉSISTANCE À L'Orobanche CHEZ LE TOURNESOL
}

\author{
RÉSUMÉ
}

Ce document se propose de faire le point des connaissances actuelles sur la résistance du tournesol à Orobanche chez le tournesol du point de vue du sélectionneur et du point de vue biochimique.

La relation parasitique Helianthus annuus/Orobanche cumana diffère par beaucoup d'aspects de celles des autres espèces Orobanche spp. avec leurs hôtes.

La difficulté majeur pour le sélectionneur est le développement rapide de nouveaux pathotypes de Orobanche cumana, qui contourne la résistance des lignées de tournesol nouvellement développées. La base d'une augmentation de l'agressivité des pathotypes de Orobanche cumana est discutée.

Néanmoins, il y a un potentiel encore important d'amélioration de la résistance au sein du genre Helianthus, du fait que les facteurs de résistance très différents sont déjà connus ou seront élucidés

Une revue est présentée sur les facteurs connus de résistance, tels que la faible stimulation, les barrières mécaniques et la façon dont elles se mettent en place, les phytoalexines, les inhibiteurs de la germination des graines d'Orobanche, l'inhibition des exoenzymes des radicules d' Orobanche et en particulier de la polygalacturonase, qui rend possible la pénétration des tissus d' Orobanche à l'intérieur de la racine de l' hôte. Dans ce contexte une nouvelle approche intéressante peut être trouvée dans les protéines inhibitrices de la polygalacturonase qui se trouvent dans les parois cellulaires, et qui inhibent l'invasion du pathogène.

Le besoin d' études de biologie moléculaire est souligné.

Une collaboration interdisciplinaire des sélectionneurs avec les biochimistes et les biologistes moléculaires peut conduire à des stratégies de sélection plus avancées. 
